\title{
Note
}

\section{Colonization of the Beaufort Coastal Plain by Beaver (Castor canadensis): A Response to Shrubification of the Tundra?}

\author{
Thomas S. Jung ${ }^{1,5}$, Jay Frandsen ${ }^{2}$, Danny C. Gordon, SR. ${ }^{3}$, and David H. Mossop ${ }^{4}$ \\ ${ }^{1}$ Yukon Department of Environment, P.O. Box 2703, Whitehorse, Yukon Y1A 2C6 Canada \\ ${ }^{2}$ Western Arctic Field Unit, Parks Canada, P.O. Box 1840, Inuvik, Northwest Territories X0E 0T0 Canada \\ ${ }^{3}$ Aklavik Hunters and Trappers Committee, P.O. Box 133, Aklavik, Northwest Territories X0E 0A0 Canada \\ ${ }^{4}$ Yukon Research Centre, Yukon College, P.O. Box 2799, Whitehorse, Yukon Y1A 5K4 Canada \\ ${ }^{5}$ Corresponding author: thomas.jung@gov.yk.ca
}

Jung, Thomas S., Jay Frandsen, Danny C. Gordon, Sr., and David H. Mossop. 2016. Colonization of the Beaufort Coastal Plain by Beaver (Castor canadensis): a response to shrubification of the tundra? Canadian Field-Naturalist 130(4): 332-335.

A consequence of rapid global warming has been the shrubification (increase in shrub abundance, cover, and biomass) of arctic and alpine tundra ecosystems. Shrubification is likely a key driver of predicted and observed changes in the biodiversity of the Arctic. The American Beaver (Castor canadensis) has a vast distributional range, covering most of North America below the tree line; however, it has not been recorded in tundra habitat of the Beaufort Coastal Plain of Yukon and Alaska. In 2015, we observed a beaver dam, lodge, and winter food cache on the Babbage River in Ivvavik National Park, Yukon, Canada. Local Inuvialuit hunters first observed beavers on two rivers immediately east of the Babbage River in 2008 and 2009. Together, these are the first observations of beavers on the Beaufort Coastal Plain and indicate initial attempts at colonization. Colonization of the Beaufort Coastal Plain by beavers may have been facilitated by shrubification of river valleys on the tundra of northern Yukon and adjacent Alaska, which is a consequence of rapid climate warming in the western Arctic.

Key Words: American Beaver; Beaufort Coastal Plain; Castor canadensis; climate change impacts; range expansion; shrubification; tundra; Yukon North Slope

The Arctic is undergoing dramatic ecological changes as a result of rapid climate warming (Post et al. 2009). One of the most concerning changes is the rapid shrubification (increase in shrub abundance, cover, and biomass) of tundra ecosystems by Salix spp., Betula spp., and Alnus spp. (Sturm et al. 2001; Tape et al. 2006; Myers-Smith et al. 2011a,b). Shrubification can have a substantial impact on soil temperatures, nutrient cycling, biodiversity, and ecological services in arctic and alpine tundra ecosystems (Myers-Smith et al. 2011a).

A striking example of climate-induced changes in mammalian biodiversity in the Arctic is the recent colonization by the Snowshoe Hare (Lepus americanus) of tundra riparian systems in Alaska, likely as a result of shrubification (Tape et al. 2016a). Over longer periods, Moose (Alces americanus) have similarly expanded their range onto the tundra of Alaska and northwestern Canada, also likely as a result of shrubification (Coady 1980; Tape et al. 2016b). With continued global warming and the concomitant increase in shrubification, other mammals more characteristic of subarctic regions may be expected to colonize the tundra as well, with possible impacts on the biota and ecological functioning of those ecosystems. On the North Slope of Yukon and Alaska (hereafter, Beaufort Coastal Plain), shrubification has been concentrated along river valley corridors (Naito and Cairns 2015; Tape et al. 2016a), which may aid in the movement and dispersal of species colonizing the tundra.
The American Beaver (Castor canadensis) has an immense distributional range that extends through much of the United States and Canada below the tree line (Jenkins and Busher 1979; Baker and Hill 2003). It has also been successfully introduced in regions of South America and Europe. In North America, beavers may occur at high latitudes, such as in the Mackenzie River Delta, where they occupy forested landscapes (Aleksiuk 1970; Gill 1972); however, Baker and Hill (2003) noted that "they have been unable to colonize Alaskan or Canadian arctic tundra, perhaps because tundra vegetation lacks essentially woody plants for winter food and lodge construction or because thick ice limits surface access in winter." Indeed, observations of beavers on the tundra are uncommon, although they have been incidentally observed immediately east of the Mackenzie River Delta (O. E. Barker, personal communication), where they are relatively close and hydrologically connected to forested areas where ample shrubs are available for forage and lodge construction. Regardless, arctic tundra is atypical habitat for beavers. Here, we report the first observation of a beaver on the Beaufort Coastal Plain of Yukon and Alaska, an ecological region that is not hydrologically connected to forested watersheds (Craig and McCart 1975) or previously known to be inhabited by beavers (Baker and Hill 2003).

On 22 July 2015, we observed a beaver dam on the Babbage River $\left(68.95430^{\circ} \mathrm{N}, 138.53500^{\circ} \mathrm{W}\right)$, about 26 $\mathrm{km}$ south of the coast of the Beaufort Sea, in Ivvavik 
National Park, Yukon, Canada, and about 210 km northwest of Inuvik, Northwest Territories. We found the dam while conducting an aerial survey of cliff-dwelling raptors from a helicopter flying approximately $30 \mathrm{~m}$ above the ground. The dam was in a small side channel to the west of the main stem of the river at an elevation of about $60 \mathrm{~m}$ above sea level. On 22 September 2015, while en route to conduct other work, we returned by helicopter and located and photographed the dam, along with a beaver lodge and winter food cache (Figure 1). The presence of a newly constructed food cache demonstrated that the site was occupied by beavers. The food cache was composed of shrubs, and the dam and lodge were built of mud and woody material from shrubs. As our aerial survey was focussed on cliff habitats, we were unable to survey the extent of the Babbage River or adjacent rivers to search for other signs (e.g., dams, lodges) of beaver occupancy.

Based on accounts of mammal distribution in the region (e.g., Youngman 1975; Slough and Jung 2007; MacDonald and Cook 2009), distribution maps in detailed species accounts of beavers (Jenkins and Busher 1979; Baker and Hill 2003), online museum records (e.g., ARCTOS), and personal communication with Yukon biologists and park wardens (see Acknowledgements) and local Inuvialuit hunters and trappers who have had extensive experience on the Beaufort Coastal
Plain in the past $\leq 40$ years, beavers are not known from the Beaufort Coastal Plain in Yukon. Indeed, when describing the northern extent of beaver, Baker and Hill (2003) commented that "they were widespread in Alaska, except along the Arctic Slope from Point Hope east to the Canadian border".

Local Inuvialuit hunters had first observed evidence (i.e., dam and house) of a single colony on the Blow River in 2008 and the Running River in 2009 (D.C.G., personal observation), which are about $60-65 \mathrm{~km}$ and $50 \mathrm{~km}$ east of the Babbage River, respectively. Thus, our observation on the Babbage River in 2015, coupled with earlier observations by Inuvialuit hunters on adjacent rivers in 2008 and 2009, apparently constitute the first evidence of beavers on the Beaufort Coastal Plain.

We do not know how beavers reached the Beaufort Coastal Plain, but they would have had to cross a mountain range or swim in the sea, both of which are likely significant barriers to dispersal. All rivers on the Beaufort Coastal Plain flow north to the Beaufort Sea and are not hydrologically connected to any forested subarctic watershed (Craig and McCart 1975). The continental divide between the watersheds on the Beaufort Coastal Plain and those to the south are separated by rugged mountains. Moreover, for beavers to have moved from the Mackenize River Delta, where they occur, to rivers on the Beaufort Coastal Plain would

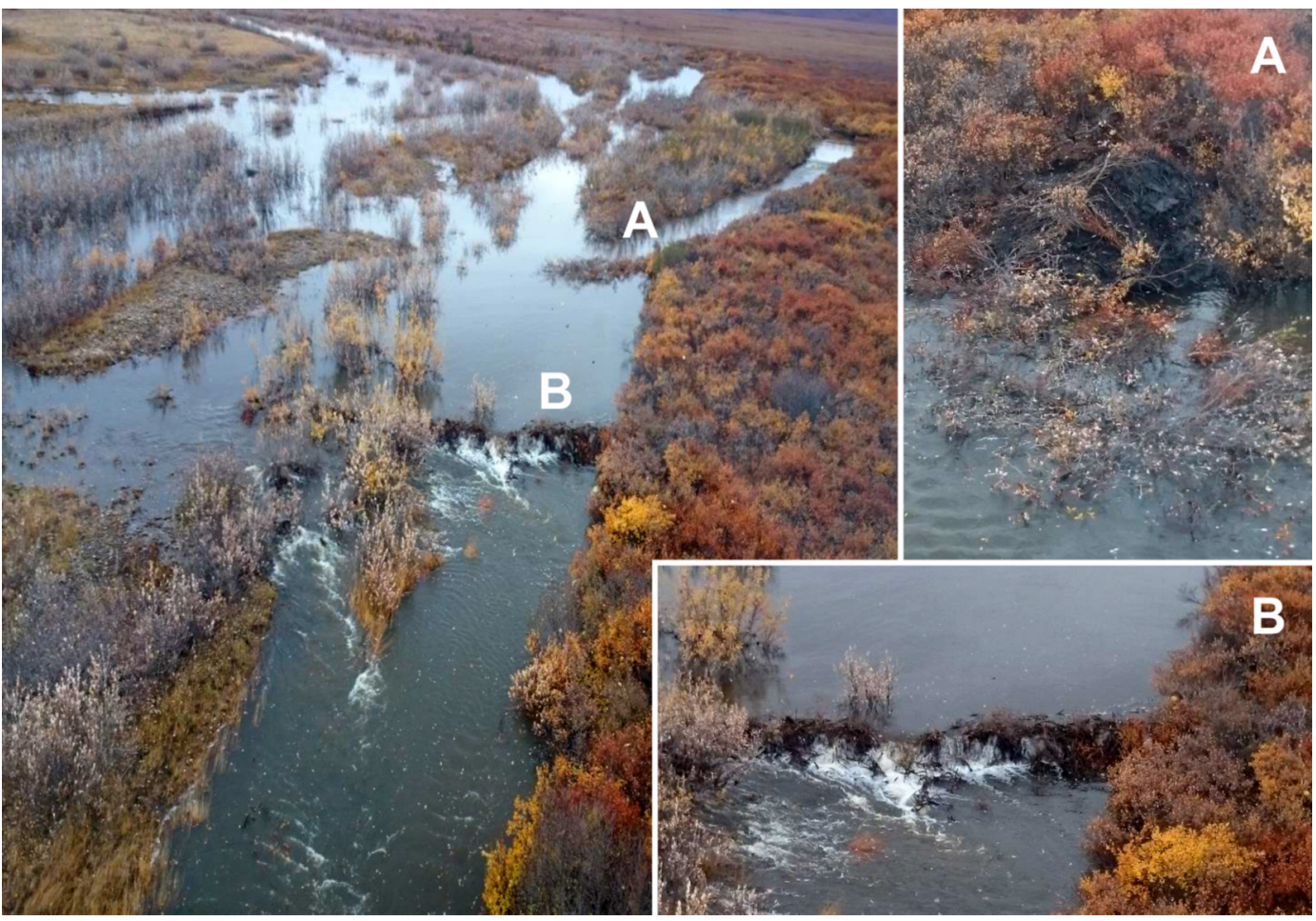

FIGURE 1. Photographs of an American Beaver (Castor canadensis) winter food cache (A) and dam (B) on the Babbage River, Ivvavik National Park, Yukon, Canada, 22 September 2015. Insets show details of the lodge and winter food cache (A) and the dam (B). Photos: J. Frandsen. 
require travelling west along the coast of the Beaufort Sea. Dispersal of beavers from the Mackenzie Delta may be a response to increased beaver density there in recent years as observed by local Inuvialuit hunters (D.C.G., personal observation).

Jarema et al. (2009) demonstrated that beaver respond strongly to climate warming, both by expanding its range and by increasing its abundance at the core of its range. In terms of range expansion, beavers are similar to Moose (Tape et al. 2016b) and Snowshoe Hare (Tape et al. 2016a) in that they would be expected to benefit from shrubification of tundra environments because they can forage extensively on shrubs (Aleksiuk 1970; Busher 1996), and they also use shrubs as building materials for their lodges and dams (Jung and Staniforth 2010). Given that shrubification of the Beaufort Coastal Plain is underway (Myers-Smith et al. 2011b; Naito and Cairns 2015; Tape et al. 2016a) and has likely increased habitat suitability for beavers, it is plausible that they could colonize waterbodies there, once barriers to colonization (i.e., mountain passes or the ocean) were successfully crossed.

Beaver occupancy of the Beaufort Coastal Plain is of interest from at least three perspectives. First, coupled with other recent reports (Jung and Staniforth 2010; Elsey et al. 2015), our observation points to the remarkable adaptability of beaver to colonize atypical habitats. Second, it further demonstrates the changes in mammalian communities that are occurring in the Arctic as a result of climate-induced shrubification of riparian areas, similar to those pointed out by Tape et al. (2016 a,b). Finally, because beaver are a keystone species that modifies ecosystems (reviewed by Rosell et al. 2005), their colonization of the Beaufort Coastal Plain may induce changes in the local landscape and hydrology, with concomitant impacts on the biodiversity of riverine and riparian ecosystems (e.g., riparian birds [Cooke and Zack 2008] and anadromous fish [Malison et al. 2014]). Thus, it would be prudent to monitor for changes in beaver abundance and distribution on the Beaufort Coastal Plain and ecological changes that may be a result of their colonization.

\section{Acknowledgements}

We thank O. Barker, B. Bennett, C. Eckert, R. Gordon, M. Kienzler, R. Maraj, B. Slough, and M. Suitor (Yukon Department of Environment); D. Reid (Wildlife Conservation Society); and P. Sinkins (Parks Canada) for collating and sharing observations of the fauna of the Yukon North Slope. We thank R. Gordon and T. Powell (Yukon Department of Environment) and P. Sinkins for logistical support. Funding for the survey that yielded this observation was provided by Parks Canada, the Wildlife Management Advisory Council (North Slope), Yukon Department of Environment, and Yukon College. M. Obbard, D. Lepitzki, and two anonymous reviewers provided comments that improved this note.

\section{Literature Cited}

Aleksiuk, M. 1970. The seasonal food regime of arctic beavers. Ecology 51: 264-270.

Baker, B. W., and E. P. Hill. 2003. Beaver (Castor canadensis). Pages 288-300 in Wild Mammals of North America: Biology, Management, and Conservation. Second Edition. Edited by G. A. Feldhamer, B. C. Thompson, and J. A. Chapman. Johns Hopkins University Press, Baltimore, Maryland, USA.

Busher, P. E. 1996. Food caching behavior of beaver (Castor canadensis): selection and use of woody species. American Midland Naturalist 135: 343-348.

Coady, J. 1980. History of moose in northern Alaska and adjacent regions. Canadian Field-Naturalist 94: 61-68.

Cooke, H. A., and S. Zack. 2008. Influence of beaver dam density on riparian areas and riparian birds in shrubsteppe of Wyoming. Western North American Naturalist 68: 365373.

Craig, P. C., and P. J. McCart. 1975. Classification of stream types in Beaufort Sea drainages between Prudhoe Bay, Alaska, and the Mackenzie Delta, N. W. T., Canada. Arctic and Alpine Research 7: 183-198.

Elsey, R. M., S. G. Platt, and M. Shirley. 2015. An unusual beaver (Castor canadensis) lodge in a Louisiana coastal marsh. Southeastern Naturalist 14: 28-30.

Gill, D. 1972. The evolution of a discrete beaver habitat in the Mackenzie River Delta, Northwest Territories. Canadian Field-Naturalist 86: 233-239.

Jarema, S. I., J. Samson, B. J. McGill, and M. M. Humphries. 2009. Variation in abundance across a species' range predicts climate change responses in the range interior will exceed those at the edge: a case study with North American beaver. Global Change Biology 15: 508-522.

Jenkins, S. H., and P. E. Busher. 1979. Castor canadensis. Mammalian Species 120: 1-8.

Jung, T. S., and J. A. Staniforth. 2010. Unusual Beaver, Castor canadensis, dams in central Yukon. Canadian FieldNaturalist 124: 274-275.

MacDonald, S. O., and J. A. Cook. 2009. Recent Mammals of Alaska. University of Alaska Press, Anchorage, Alaska, USA.

Malison, R. L., M. S. Lorang, D. C. Whited, and J. A. Stanford. 2014. Beavers (Castor canadensis) influence habitat for juvenile salmon in a large Alaskan river floodplain. Freshwater Biology 59: 1229-1246.

Myers-Smith, I. H., B. C. Forbes, M. Wilmking, M. Hallinger, T. Lantz, D. Blok, K. D. Tape, M. MaciasFauria, U. Sass-Klaassen, E. Lévesque, S. Boudreau, P. Ropars, L. Hermanutz, A. Trant, L. Siegwart Collier, S. Weijers, J. Rozema, S. A. Rayback, N. M. Schmidt, G. Schaepman-Strub, S. Wipf, C. Rixen, C. B. Ménard, S. Venn, S. Goetz, L. Andreu-Hayles, S. Elmendorf, V. Ravolainen, J. Welker, P. Grogan, H. E. Epstein, and D. S. Hik. 2011a. Shrub expansion in tundra ecosystems: dynamics, impacts and research priorities. Environmental Research Letters 6.

Myers-Smith, I. H., D. S. Hik, C. Kennedy, D. Cooley, J. F. Johnstone, A. J. Kenney, and C. J. Krebs. 2011b. Expansion of canopy-forming willows over the twentieth century on Herschel Island, Yukon Territory, Canada. Ambio 40: 610-623.

Naito, A. T., and D. M. Cairns. 2015. Patterns of shrub expansion in Alaskan arctic river corridors suggest phase transition. Ecology and Evolution 5: 87-101. 
Post, E., M. C. Forchhammer, M. S. Bret-Harte, T. V. Callaghan, T. R. Christensen, B. Elberling, A. D. Fox, O. Gilg, D. S. Hik, T. T. Høye, R. A. Ims, E. Jeppesen, D. R. Klein, J. Madsen, A. D. McGuire, S. Rysgaard, D. E. Schindler, I. Stirling, M. P. Tamstorf, N. J. C. Tyler, R. van der Wal, J. Welker, P. A. Wookey, N. M. Schmidt, and P. Aastrup. 2009. Ecological dynamics across the Arctic associated with recent climate change. Science 325 : $1355-1358$.

Slough, B. G., and T. S. Jung. 2007. Diversity and distribution of the terrestrial mammals of the Yukon Territory: a review. Canadian Field-Naturalist 121: 119-127.

Sturm, M., C. H. Racine, and K. D. Tape. 2001. Increasing shrub abundance in the Arctic. Nature 411: 546-547.

Tape, K. D., K. Christie, G. Carroll, and J. A. O'Donnell. 2016a. Novel wildlife in the Arctic: the influence of changing riparian ecosystems and shrub habitat expansion on snowshoe hares. Global Change Biology 22: 208-219.
Tape, K. D., D. D. Gustine, R. W. Ruess, L. G. Adams, and J. A. Clark. 2016b. Range expansion of moose in Arctic Alaska linked to warming and increased shrub habitat. PloS One 11: e0152636.

Tape, K. D., M. Sturm, and C. H. Racine. 2006. The evidence for shrub expansion in northern Alaska and the panArctic. Global Change Biology 12: 686-702.

Rosell, F., O. Bozser, P. Collen, and H. Parker. 2005. Ecological impact of beavers Castor fiber and Castor canadensis and their ability to modify ecosystems. Mammal Review 35: $248-276$.

Youngman, P. M. 1975. Mammals of the Yukon Territory. Publications in zoology 10. National Museum of Canada, Ottawa, Ontario, Canada.

Received 15 May 2016

Accepted 25 October 2016 